\title{
Communication
}

[Comunicação]

\section{Renal dysplasia in a Limousin calf}

\author{
[Displasia renal em um bezerro Limousin] \\ M.B. Castro $^{1}$, M.P.J. Szabó ${ }^{2}$, W.L. Ferreira ${ }^{3 *}$, A.A. Pereira ${ }^{4}$ \\ ${ }^{1}$ Universidade de Brasília - Brasília, DF \\ ${ }^{2}$ Faculdade de Medicina Veterinária - UFU - Uberlândia, MG \\ ${ }^{3}$ Curso de Medicina Veterinária - FOA - UNESP \\ Rua Argentina, 340 \\ 16025-240 - Araçatuba, SP \\ ${ }^{4}$ Curso de Medicina Veterinária - UNIFRAN - Franca, SP
}

Renal dysplasia is a disorganised development of renal parenchyma due to anomalous differentiation (Maxie, 1993) and it is a well known entity in man (Welling and Granthan, 1991) and dog (Picut and Lewis, 1987). It has also been characterized in horse (Anderson et al., 1988; Ronen et al., 1993) and lamb (Jones et al., 1990), urith, only a few cases have been reported in bovine (Dunhan et al., 1989; Ohba et al., 2001).

This short communication describes renal dysplasia in a four-month-old male Limousin calf. According to the owner, the calf presented loss of weight, low growth rate, anorexia, apathetic and dark foetid diarrhoea for one month. No other similar case occurred in the herd. On clinical examination, depression, weakness and anorexia were observed. The major laboratory findings included azotemia (urea: $303.0 \mathrm{mg} / \mathrm{dl}$ and creatinine: $17.6 \mathrm{mg} / \mathrm{dl}$ ), low urinary specific gravity (1010) and neutrophilia. In spite of treatment no improvement in clinical signs occurred and uraemia persisted. The prognosis was considered poor and the calf was euthanized to avoid further suffering.

At necropsy both kidneys were small, firm, pale and had a roughened surface. The capsule was firmly adhered to the irregular subcapsular surface. The cortex showed diffuse pale fibrous appearance, white multiple focus of fibrosis and the corticomedullary junction was indistinct. Tissues fragments of most organs were collected, fixed in $10 \%$ buffered formalin and processed according to the routine of histopathology techniques. Paraffin sections at $4 \mu \mathrm{m}$ were stained with haematoxylin and eosin. Sections of kidney were also stained with alcian blue and Masson's trichrome for connective tissue evaluation. The histological examination of the kidneys showed multiple immature glomeruli with peripheral nuclei, unapparent capillaries and arboreal pattern (Fig. 1). The renal cortex presented primitive tubules lined by cuboidal or columnar epithelium surrounded by loose mesenchyme that stained only with alcian blue (Fig. 2), but not with Masson's trichrome. Mild interstitial fibrosis in the renal medulla was observed. Both kidneys showed structures in inappropriate stage of development or anomalous. Other organs did not display noteworthy histopathological findings.

The calf presented most of the significant microscopic features used as criteria to characterize renal dysplasia (Maxie, 1993). Even though it was very young it already presented severe uraemia due to reduced functional capacity determined by the renal malformation. In this case, causes for the malformation are unknown and explanations are speculative. Immature glomeruli and formation of primitive ducts might have resulted from abnormal development of metanephric blastema and ducts as already supposed (Picut and Lewis, 1987; Welling and Granthan, 1991). The causes of renal dysplasia are usually hereditary but teratogenic agents can produce the disease. Fetal viral infection is associated with renal dysplasia in most species (Maxie, 1993). In dogs, renal dysplasia has been frequently described associated to breeds and

Recebido em 31 de janeiro 2006

Aceito em 9 de janeiro de 2007

*Corresponding author (autor para correspondência)

E-mail: wluis@fmva.unesp.br 
familial autosomal disease is suspected (Maxie, 1993). Bovine diarrhoea virus infection has been incriminated as a cause of renal dysplasia in calves (Maxie, 1993). Japanese Black beef cattle presented hereditary autosomal recessive kidney disease in calves characterized by growth retardation, renal tubular dysplasia and fatal uraemia (Ohba et al., 2001). The loccus responsible for the disease was mapped within a region on bovine chromosome 1 . The deletion of the parecellin-1 gene was pointed to be responsible for tubular renal dysplasia in Japanese black beef cattle (Ohba et al., 2000).

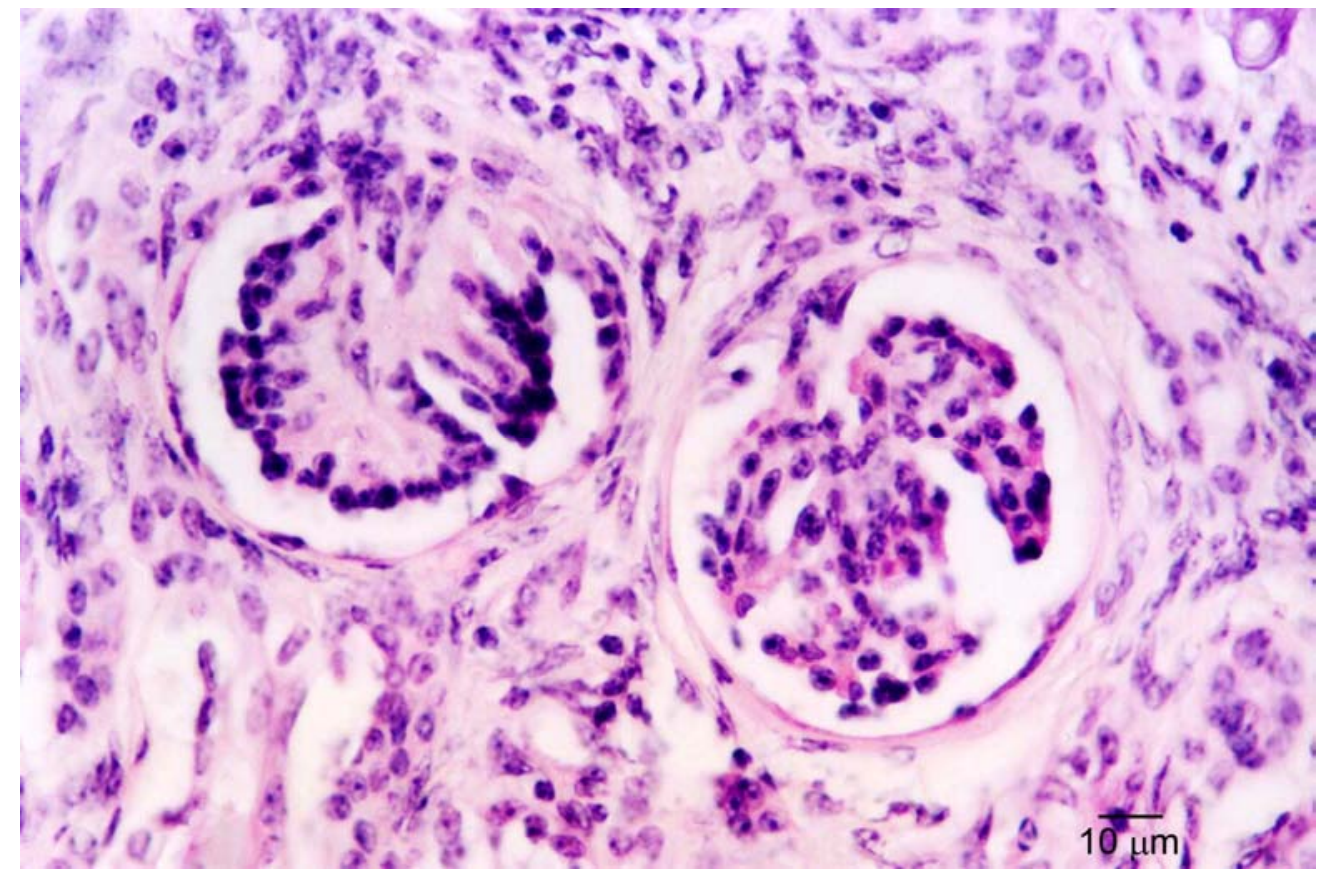

Figure 1. Immature glomeruli with unapparent capillaries and arboreal pattern. (Hematoxylin and eosin).

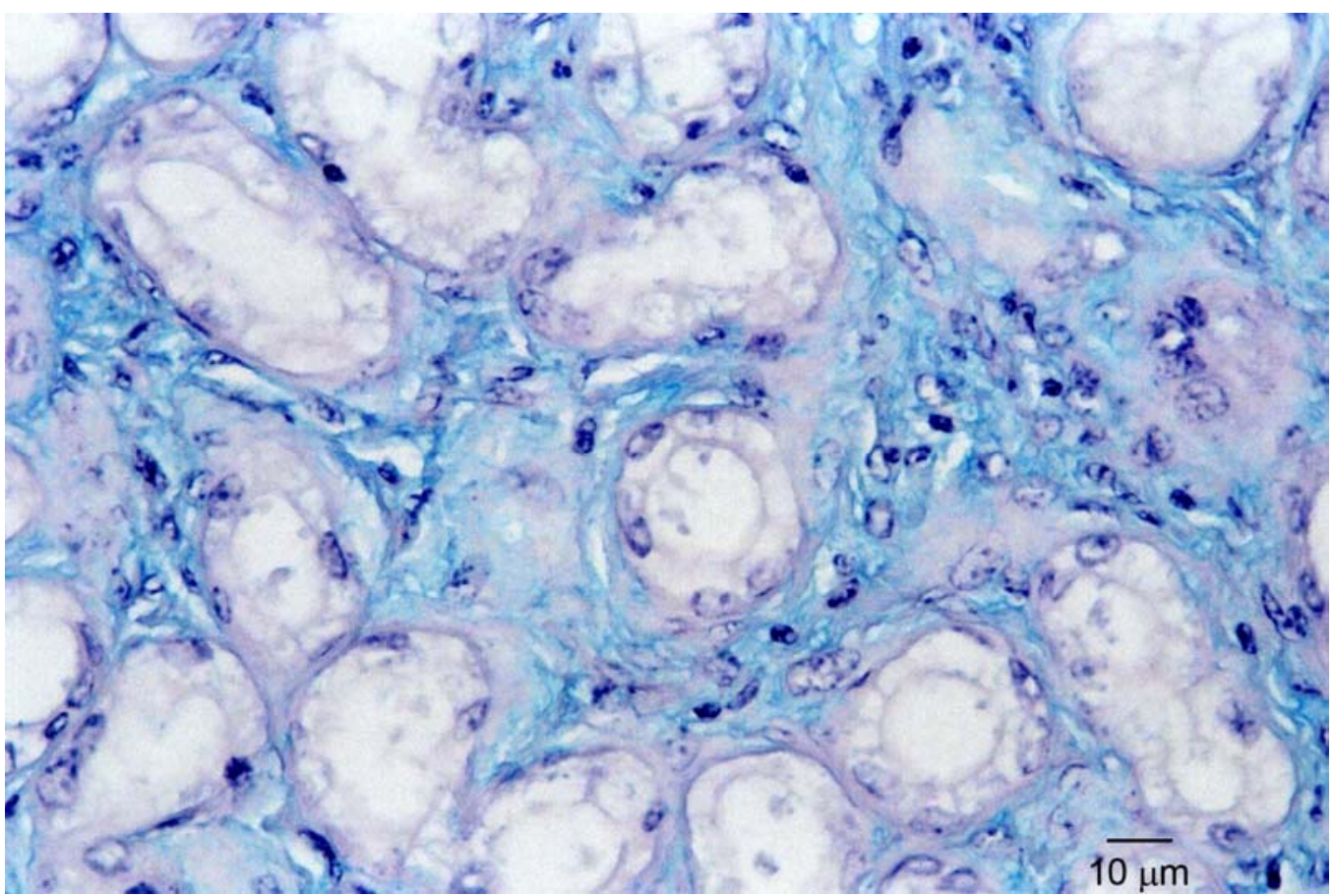

Figure 2. Primitive tubules lined by cuboidal epithelium surrounded by loose mesenchyme. (Alcian blue). 
There was no evidence of bovine diarrhea virus fetal infection or other known hereditary bovine malformation in this case. Since bovine renal dysplasia has not been previously reported in Limousin breed, it could not be concluded about the etiology and occurrence rate of renal dysplasia. Limousin calf in indeed, most bovine malformations are poorly understood and better knowledge about them is desirable.

Keywords: calf, Limousin, renal dysplasia, histopathological

\section{ACKNOWLEDGMENTS}

The authors would like to acknowledge José Luis de Souza and Marcos Alexandre de Souza for preparing the slides for microscopic analysis.

\section{RESUMO}

Descreve-se um caso de displasia renal em um bezerro Limousin, macho, de quatro meses. O animal apresentava perda de peso, baixa taxa de crescimento, anorexia, apatia, diarréia escura fétida e uremia, sem melhora apesar de tratamento. $O$ bezerro foi sacrificado para interromper o sofrimento adicional $e$ submetido à necropsia. Ao exame foi observado que os rins estavam pequenos, firmes, pálidos e com superfície rugosa. A cápsula estava aderida à uma superfície subcapsular irregular. O córtex tinha aparência difusamente pálida e fibrosa e apresentava múltiplos focos brancos de fibrose. A junção córtico-medular estava indistinta. $O$ exame histologico dos rins revelou múltiplos glomérulos imaturos com núcleo periférico, capilares inaparentes e padrão arbóreo. O córtex renal apresentou túbulos primitivos com epitélio cubóide ou cilíndrico envolvido por mesênquima corado somente pelo alcian blue e não pelo tricrômico de Masson. Foi também observada leve fibrose intersticial na medula renal. Os rins mostravam estruturas em estágio inapropriado de desenvolvimento ou anômalas.

Palavras-chave: bezerro, Limousin, displasia renal, histopatologia

\section{REFERENCES}

ANDERSON, W.I.; PICUT, C.A.; KING, J.M. et al. Renal dysplasia in a standardbred colt. Vet. Pathol., v.25, p.180-181, 1988.

DUNHAN, B.M.; ANDERSON, W.I.; STEINBERG, H. et al. Renal dysplasia with multiple urogenital and large intestinal anomalies in a calf. Vet. Pathol., v.26, p.94-96, 1989.

JONES, T.O.; CLEGG, F.G.; MORGAN, G. et al. Vertically transmitted cystic renal dysplasia of lambs. Vet. Rec., v.127, p.421-424, 1990.

MAXIE, M.G. Renal dysplasia. In: JUBB, K.V.F.; KENNEDY, P.C.; PALMER, N. (Eds). Pathology of domestic animals. 4.ed. San Diego: Academic, 1993. v.2, p.461-463.

OHBA, Y.; KITAGAWA, H.; KITOH, K. et al. Deletion of the paracellin-1 gene is responsible for renal tubular dysplasia in cattle. Genomics, v.68, p.229-236, 2000.

OHBA, Y.; KITAGAWA, H.; KITOH, K. et al. Inheritance of renal tubular dysplasia in Japanese black cattle. Vet. Rec., v.149, p.153-154, 2001

PICUT, C.A.; LEWIS, R.M. Microscopic features of canine renal dysplasia. Vet. Pathol., v.24, p.156-163, 1987.

RONEN, N.; VAN AMSTEL, S.R.; NESBIT, J.W. et al. Renal dysplasia in two adult horses: clinical an pathological aspects. Vet. Rec. v.132, p.269-270, 1993.

WELLING, L.W.; GRANTHAN, J.J. Cystic and developmental diseases of the kidney. In: BRENNER, B.M.; PRECTOR, F.C. (Eds). The Kidney. 4.ed. Philadelphia: W.B. Saunders, 1991. v.2, p.1657-1694. 